\title{
Female human resource professionals' job embeddedness in relation to commitment foci: An exploratory study
}

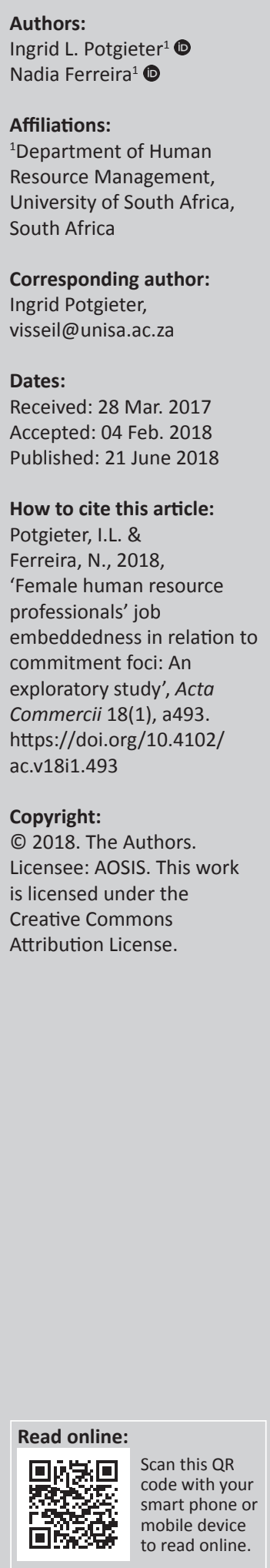

Orientation: Managers and human resource practitioners who are concerned about managing talent as a critical resource need to recognise how employees' job embeddedness relates to their commitment foci within the organisation. By understanding this relationship, gaps can be identified and talent can be managed optimally.

Research purpose: The purpose of the study was, firstly, to establish whether a significant relationship exists between job embeddedness and a set of commitment foci and, secondly, to identify the variables that contribute the most to the relationship.

Motivation for the study: Organisations increasingly devote more attention to initiatives that enhance the commitment and job embeddedness of their employees in order to assist in the design of a sound talent management plan to close the talent gaps.

Research approach, design and method: A quantitative approach was used in this study, utilising a cross-sectional survey design to achieve the objective of the study. Descriptive statistics, Pearson's product-moment correlations and canonical correlation analysis were conducted. The participants were primarily black women at an early stage of their career, who were employed in the human resource management field in a professional capacity.

Main findings: The results indicated that job embeddedness significantly and positively accounted for the variance in organisational and occupational commitment foci of the participants.

Practical and managerial implications: Human resource practitioners and managers need to consider how the job embeddedness of employees - specifically female employees - affects their commitment foci in developing talent management plans as part of the organisational strategy.

Conclusions: The findings of the study provided empirical confirmation of theoretical views on the psychological aspects that keep employees embedded in their jobs and how these aspects relate to their commitment foci.

\section{Introduction}

\section{Background to the study}

Organisations are facing considerable challenges in retaining valuable employees in an exceedingly competitive global market (Ruvimbo \& Hlanganipai 2016:74). Retaining committed employees is especially challenging in South Africa, given the post-apartheid concerns of fair employment and leadership opportunities for black South Africans (Kock \& Burke 2008:457). Inequality contributes to low job satisfaction and high turnover rates (Booysen 2007:47; Dyk \& Coetzee 2013:61; Tabane, Bosch \& Roodt 2013:39; Williamson \& Holmes 2015:226). Staff retention has become a multidimensional issue faced by most of the organisations in the 21st century world of work. The most complex challenge facing organisations is to attract and retain highly competent human resources, specifically within the exceedingly turbulent business environment that competes for scarce skills in times of global skills shortages (Brundage \& Koziel 2010; Burke \& Ng 2006:86; Chabault, Hulin \& Soparnot 2012; Tladinyane, Coetzee \& Masenge 2013:140). Previous studies have shown that current talent management and retention practices are a competitive advantage in today's global economy (Hebenstreit 2008; Reiche 2007; Ruvimbo \& Hlanganipai 2016:74). Committed and engaged employees are regarded as valuable assets within organisations (Bothma \& Roodt 2012:893; Coetzee, Schreuder \& Tladinyane 2014:572). Therefore, organisations continue to emphasise human resource initiatives that increase the commitment, job embeddedness, 
satisfaction and engagement of their employees in order to retain valuable employees (Coetzee et al. 2014:572; Ferreira \& Coetzee 2014:9).

Job embeddedness is a multidimensional construct that incorporates the specific links or combination of relationships that employees develop with other individuals (both on and off the job) (Felps et al. 2009:545). These links or relationships include activities performed on the job or in the community. Job embeddedness further includes the perceived fit between employees' and employer's values, as well as the sacrifice that would be made if an employee leaves his or her job and community (Lee et al. 2004:711; Marisi, Cox \& Bennett 2016:142; Mitchell, Holtom \& Lee 2001:97; Tabak \& Hendy 2016:24; Williamson \& Holmes 2015:226). Previous research (Hom et al. 2009:277; Mitchell et al. 2001:96; Zhang, Fried \& Griffeth 2012:220) indicated the significance of job embeddedness for various individual-level outcomes (e.g. commitment, turnover and performance). In addition, individuals with a high level of job embeddedness (the blend of organisational forces that keep an individual from leaving his or her job) seem to experience higher job satisfaction, which, in turn, positively influences the turnover intention (Van Dyk, Coetzee \& Takawira 2013:58). While research findings suggest that job embeddedness can play a vital role in shaping employees' organisational commitment and retention attitudes and behaviour, many uncertainties still remain with regard to how the nature of this relationship may vary based on different employee attributes.

Several research studies have been conducted on organisational commitment in the South African retention context. Organisational commitment reflects an employee's commitment towards an organisation in terms of their emotional responses to or feelings about organisational issues or foci, which influence their psychological attachment towards the organisation (Mitchell et al. 2001:102; Roodt 1997:6). Several studies found that organisational commitment is a significant predictor of employee turnover (Döckel 2003; Ferreira 2010, 2012; Lumley 2009; Roodt 1997; Van Dyk \& Coetzee 2012). Meyer and Allen (1997) and Tladinyane et al. (2013:141) have explained that employees' level of commitment depends on how they make sense of or interpret their work-related context.

Several authors have acknowledged commitment as a significant aspect of understanding an employee's work behaviour (Mowday, Porter \& Steers 1982; Veurink \& Fischer 2011:162). By taking previous studies into consideration, there is relative agreement that commitment is multidimensional (Martin \& Roodt 2016:24; Meyer et al. 2002:22; Podnar \& Golob 2015:215). Previously, research on commitment focused on commitment in terms of the organisation; however, more and more research is being conducted on the different foci of commitment (referring to the units, objects, persons or organisational aspects) to which individuals may feel committed (Cohen 2003; Wasti \& Onder 2009:310; Yousaf,
Yang \& Sanders 2015:135). Despite the apparent importance attached to employees' job embeddedness and occupational and organisational commitment, there seems to be a general lack of research on the association between these constructs, especially in the South African workplace.

The study explored the relationship between individuals' job embeddedness and their work-related commitment, as well as determined the variables that contribute the most to this relationship. Both of these constructs represent psychological forces and attitudes that influence the retention of valuable staff (Coetzee et al. 2014:572). Research conducted by Rubel and Kee (2015) among nurses showed important associations between organisational commitment and job retention. A study conducted by Ferreira (2012) indicated a positive relationship between job embeddedness and organisational commitment of employees. The present study elaborates on previous research by focusing on the employed professional graduates in the field of human resource management (HRM) and by investigating the different facets of an individual's job embeddedness that are recognised as being important for an individual's commitment. Specifically, by employing canonical correlation analysis, we sought (1) to ascertain whether a significant relationship exists between a set of psychological forces associated with individuals' job embeddedness and their various foci of organisational commitment and (2) to identify the variables that contributed the most to this relationship.

\section{Literature review}

The theoretical beliefs described here are testable statements about the what (prescriptive) and why (interpretive) of human behaviour and social phenomena. These include all statements that form part of hypotheses, typologies, models, theories and conceptual descriptions (Mouton \& Marais 1996).

\section{Job embeddedness}

Job embeddedness is regarded as the sum of forces that ensures that employees remain embedded in their current job or occupation (Charlier, Guay \& Zimmerman 2016:109; Ferreira \& Coetzee 2014:10; Ghosh \& Gurunathan 2015:240; Halvorsen, Treuren \& Kulik 2015:1298; Marisi et al. 2016:142; Zhang et al. 2012:220). It refers to a wide range of on-the-job and off-the-job influences that attach or bind employees to the organisation and thus influence their decision to stay on the job or in the organisation. These influences establish employees' dispositional orientations or perceptions of their fit with the organisation, job and environment, the formal or informal links between them and the organisation or people, and the sacrifice they might need to make when leaving the organisation or the job (Mitchell et al. 2001:96). Job embeddedness, as a concept, therefore consists of three dimensions: 'fit' with the job, organisation and community; 'links' to other people, teams and groups; and the 'sacrifice' associated with changing jobs (Mitchell et al. 2001:104). 
- Fit refers to the perceived compatibility of one's personal values, career goals, and plans for the future with the larger corporate culture and the demands of the immediate job (i.e. skills, abilities, job knowledge), organisation and the environment'. (Mitchell et al. 2001:104). A high fit results in a high likelihood that an employee will feel personally and professionally bound to the organisation (Mitchell et al. 2001:104). Individuals who observe a good fit between their personal goals, values and skills and the organisation are more likely to remain with an organisation (Chetty, Coetzee \& Ferreira 2016:11; Redelinghuys \& Botha 2016:12).

- Links refer to 'the extent of an individual's ties with other people and activities at work to family, non-work and off-the-job interests'. The greater the number of links between an employee and the social, psychological and financial web (which includes work and nonwork friends, groups and the community, as well as the physical environment in which the employee lives), the more the employee is tied to the job and organisation (Mitchell et al. 2001:104).

- Sacrifice refers to 'the ease with which a person feels that links can be broken, or people's perceptions of what they would have to give up if they were to leave their current position' (Feldman \& Ng 2007:351). If an employee feels that they would have to give up a lot (both financially and psychologically), they are less likely to leave the job or organisation (Chetty et al. 2016:11; Mitchell et al. 2001:104; Shaw et al. 1998:512).

Job embeddedness is regarded as a key construct that influences specific on-the-job (work-related) and off-the-job (personal) factors and employee retention (Ghosh \& Gurunathan 2015:241; Mitchell et al. 2001:104; Tanova \& Holtom 2008:1553). It stands to reason that the psychological forces that are associated with individuals' sense of fit with the organisation or job, perceptions of links and sacrifices may potentially have positive associations with their foci of commitment in the workplace.

\section{Organisational commitment foci}

The study focuses on a broad range of foci relating to individuals' commitment towards an organisation, such as their commitment to their work, job, career, occupation and the organisation itself. Job commitment can be defined as an individual's level of involvement in their job, the level of importance that the individual attaches to their job and the willingness of the individual to dedicate the necessary time and energy to their job (Martin \& Roodt 2016:23; Roodt 1997:6). An individual's commitment to and involvement in their work, job and career comprises an attitude of active engagement in their work, job and career areas because of the desire to achieve set goals within these areas (Coetzee 2015:30; Ferreira, Coetzee \& Masenge 2013:31; Puah \& Ananthram 2006:112; Tladinyane et al 2013:141). Research has revealed that individuals' inner work lives, career goals, motivations and desires have an influence on their attitudes towards their job, career and their organisation (Bothma \& Roodt 2012; Coetzee 2015:30; Ferreira \& Coetzee 2010; Hirschi 2012:479; Yuan et al. 2012:1549). The reason might be that these factors act as a motivating force, which produces feelings of engagement and commitment on an individual level (Coetzee \& De Villiers 2010:27; Coetzee et al. 2014; Martin \& Roodt 2016:23; Meyer, Stanley \& Parfyonova 2012:2; Oyewobi, Suleiman \& Jamil 2012:179; Roodt 1997:6). Roodt (1997:7) suggested five foci relating to organisational commitment: work, job, career, occupation and organisation.

- Work foci refer to the loyalty of employees towards work itself. Individuals who are strongly loyal towards their job ensure that they add value to their employing organisation (Aryee, Chay \& Chew 1994:2; Meyer \& Allen 1997; Tladinyane et al. 2013:141).

- Job foci refer to an individual's dedication to a set of objectives and task requirements (Colarelli \& Bishop 1990:158). This implies that the individual will be devoted to the specific tasks or responsibilities that are linked to a particular job.

- Career foci refer to the identification and involvement of an individual in terms of their occupation (Meuller, Wallace \& Prince 1992).

- Occupation foci refer to the commitment to an identifiable and specific line of work in which an individual engages in order to earn a living at a given point in time (Lee, Carswell \& Allen 2000).

- Organisation foci refer to the individual's willingness to stay with the organisation by being more determined to fulfil the organisational goals. The individual loyalty will be determined by the extent to which an individual accepts the values and goals of the organisation as their own (Roodt 1997:7).

\section{Research method and design Research approach}

A quantitative approach, utilising a cross-sectional survey design, was followed to collect primary data.

\section{Method}

\section{Participants}

A purposive sample of adults in the workforce $(N=196)$ took part in the study. The participants were registered for further studies for a qualification in HRM at a distance learning higher education institution. They were employed in professional positions in the HRM industry and comprised predominantly black people $(80 \%)$ and females $(73 \%)$ in the early stages of their careers $(80 \%<45$ years old).

\section{Measuring instruments}

\section{Job embeddedness scale}

The participants' job embeddedness was measured by using the job embeddedness scale (JES) (Mitchell et al. 2001). 
The JES is a self-report questionnaire that includes 23 items, measuring the participants' fit (7 items, e.g. 'My co-workers are similar to $\mathrm{me}^{\prime}$ ), sacrifice (10 items, e.g. 'I have a lot of freedom on this job to decide how to pursue my goals') and links (6 items, e.g. 'I feel that people at work respect me a great deal') on a six-point Likert-type scale $(1=$ strongly disagree and $6=$ strongly agree). The JES (Mitchell et al. 2001) consists of two dimensions: the organisational and the community dimensions. The researchers found that the organisational dimension predicts employee performance better (as opposed to the community dimension). The present study therefore included only the organisational dimension in the research (Ferreira \& Coetzee 2014:20; Lee et al. 2004:720). The Cronbach's alpha coefficients (internal consistency reliabilities) for the three subscales (as obtained for the sample used in this study) were as follows: fit 0.81 , sacrifice 0.84 and links 0.72

\section{Organisational commitment foci}

The participants' organisational commitment foci were measured by means of the organisation-related commitment scale (OCS) (Roodt 1997:15). The OCS is a self-report questionnaire that includes 38 items, measuring the participants' commitment to work foci (3 items, e.g. 'To what extent should everyone have a feeling of pride at work?'), job foci (6 items, e.g. 'How involved are you in your job?'), occupational foci (5 items, e.g. 'To what extent does your occupation have special personal value to you?'), career foci ( 6 items, e.g. 'How much time do you willingly devote to your career?') and organisational foci (16 items, e.g. 'To what extent do you see yourself as part of this organisation?'). A five-point Likert-type scale ( 1 = strongly disagree and 5 = strongly agree) was used for subject responses to each of the 38 items. Cronbach's alpha coefficients for each subscale range from 0.36 to 0.87 . A study conducted by Tladinyane et al. (2013:150) confirmed the internal consistency, reliability and construct validity of the OCS in the South African context.

\section{Procedure}

The survey was conducted during a study school programme that was attended by the participants who were registered for an HRM programme. A total of 250 questionnaires were handed out and the survey yielded 196 usable questionnaires (providing a response rate of $78.4 \%$ ). Voluntary participation was invited and participants were requested to sign an informed consent form. The researcher assured the participants of privacy, anonymity and confidentiality.

\section{Statistical analysis}

Descriptive statistics (means, standard deviations and Cronbach's alpha coefficients), Pearson's product-moment correlations (using SPSS) and canonical correlation analysis (using SPSS) were performed. The researcher made use of practical significance for the interpretation of the Pearson's correlations ( $r$ ). (Cohen 1992:158). An $r$ value of less than 0.30 indicated a small practical effect, $r$ values of less than
0.49 but more than 0.30 indicated a moderate practical effect and an $r$ value of greater than 0.50 indicated a large practical effect. Multicollinearity concerns were set at an $r$ value of greater than 0.90 (Hair et al. 2010). The minimum acceptable level of significance for a canonical correlation to be statistically significant is a 0.05 (as well as the 0.01 ) level. In addition to separate tests of each canonical function, a multivariate test of all canonical roots can also be performed to evaluate the significance of discriminant functions (which include the Wilks' lambda, Hotelling's trace, Pillai's trace and Roy's gc). The relative importance of the canonical loadings was assessed by applying the cut-off criteria for canonical factorial loadings $(\geq 0.40)$. The extent of the overall correlational relationships between the two variates of a canonical function and the practical significance of the predictive ability of the canonical relationship were determined by considering the $r^{2}$-type effect size $(1-. \lambda)$; (Hair et al. 2010). Cohen's (1992) guidelines were used in the interpretation of the practical significance $\left(r^{2}\right.$ less than 0.01 for a small practical effect, $r^{2}$ less than 0.09 for a moderate practical effect and $r^{2}$ greater than 0.25 for a large practical effect). The job embeddedness attributes were treated as a set of independent variables and the organisational commitment foci attributes as the set of dependent variables. The participants' age, gender and race were used as controls to explore the relationships between the research variables.

\section{Ethical considerations}

Ethical clearance and permission (2016_RPSC_029) to conduct the research were obtained from the management of the university concerned.

\section{Results \\ Descriptive and correlations}

The most widely used test for reliability is the Cronbach's alpha reliability (Cramer \& Howitt 2011). Cramer and Howitt (2011) mention that the score should vary between 0 and 1, indicating perfect consistency. Measures with a Cronbach's alpha of 0.75 or higher are considered to be internally consistent (Cramer \& Howitt 2011). The reliability coefficients reported in Table 1 show acceptable internal consistency reliability of the two scales and the subscales. The overall reliability coefficient of the JES was very high ( $\alpha=0.81$ ), as was the reliability coefficient of the overall organisational commitment foci scale $(\alpha=0.91)$. These coefficients indicated strong overall internal consistency for the two scales.

As can be seen from Table 1, the practical effect of the significant intercorrelations among the JES and OCS variables, respectively, ranges from $r \geq 0.40 \leq 0.90$ (moderate to large effect; $p \leq 0.001$ ), indicating construct validity.

Similarly, the significant intercorrelations between the JES and OCS variables were also small to moderate in practical effect $(r \geq 0.19 \leq 0.58 ; p \leq 0.05)$, suggesting no multicollinearity, which did not pose a threat to the interpretation of the 
TABLE 1: Descriptive statistics, zero-order correlations and internal consistency reliability.

\begin{tabular}{|c|c|c|c|c|c|c|c|c|c|c|c|c|c|c|c|c|c|}
\hline No. & Variables & $M$ & SD & $\alpha$ & 1 & 2 & 3 & 4 & 5 & 6 & 7 & 8 & 9 & 10 & 11 & 12 & 13 \\
\hline 1 & Race & - & - & - & - & - & - & - & - & - & - & - & - & - & - & - & - \\
\hline 2 & Gender & - & - & - & 0.06 & - & - & - & - & - & - & - & - & - & - & - & - \\
\hline 3 & Age & - & - & - & 0.06 & $-0.17^{*}$ & - & - & - & - & - & - & - & - & - & - & - \\
\hline 4 & $\begin{array}{l}\text { Job embeddedness } \\
\text { Total }\end{array}$ & 4.17 & 0.83 & 0.81 & $0.15 *$ & 0.01 & 0.10 & - & - & - & - & - & - & - & - & - & - \\
\hline 5 & Organisational fit & 4.52 & 0.91 & 0.72 & $0.20 *$ & -0.04 & -0.01 & $0.80 * *$ & - & - & - & - & - & - & - & - & - \\
\hline 6 & Organisational links & 3.87 & 1.04 & 0.84 & 0.09 & 0.05 & $0.15^{*}$ & $0.92 * *$ & $0.50 * *$ & - & - & - & - & - & - & - & - \\
\hline 8 & $\begin{array}{l}\text { Organisational } \\
\text { commitment foci: Total }\end{array}$ & 3.84 & 0.66 & 0.91 & 0.03 & -0.10 & $0.17 *$ & $0.53^{* *}$ & $0.42 * *$ & $0.51 * *$ & $0.47 * *$ & - & - & - & - & - & - \\
\hline 9 & Work foci & 3.89 & 0.54 & 0.65 & 0.02 & -0.02 & 0.04 & $0.26^{* *}$ & $0.19 *$ & $0.24 * *$ & $0.23 * *$ & $0.55 * *$ & - & - & - & - & - \\
\hline 10 & Job foci & 3.91 & 0.61 & 0.73 & -0.08 & -0.10 & 0.06 & $0.27 * *$ & $0.26 * *$ & $0.20 * *$ & $0.21 * *$ & $0.72 * *$ & $0.45 * *$ & - & - & - & - \\
\hline 11 & Occupational foci & 3.90 & 0.55 & 0.75 & 0.01 & -0.08 & $0.17^{*}$ & $0.41 * *$ & $0.36 * *$ & $0.33 * *$ & $0.33 * *$ & $0.79 * *$ & $0.43 * *$ & $0.69 * *$ & - & - & - \\
\hline 12 & Career foci & 3.50 & 0.56 & 0.87 & -0.10 & -0.73 & 0.08 & 0.14 & 0.05 & $0.18^{*}$ & 0.14 & $0.66 * *$ & $0.26 * *$ & $0.43^{* *}$ & $0.55 * *$ & - & - \\
\hline 13 & Organisational foci & 4.26 & 0.43 & 0.91 & 0.09 & -0.07 & 0.13 & $0.57 * *$ & $0.46 * *$ & $0.54 * *$ & $0.51 * *$ & $0.88 * *$ & $0.34 * *$ & $0.42 * *$ & $0.50 * *$ & $0.41 * *$ & - \\
\hline
\end{tabular}

Notes: Sample size, $N=196$.

M, mean; SD, standard deviation; 1, race; 2, gender; 3, age; 4, job embeddedness total; 5, organisational fit; 6, organisational links; 7, organisational sacrifice; 8 , organisational commitment total; 9, work foci; 10 , job foci; 11 , occupational foci; 12 , career foci; 13 , organisational foci.

$*, p \leq 0.05$ - statistically significant; $* *, p \leq 0.01$ - statistically significant; $* * *, p \leq 0.001$ - statistically significant.

$r \leq 0.30$ (small practical effect size); $r \geq 0.30 \leq 0.49$ (medium practical effect size); $r \geq 0.50$ (large practical effect size).

TABLE 2: Results of the standardised canonical correlation analysis for the first canonical function

\begin{tabular}{|c|c|c|c|c|}
\hline Variate/variables & Canonical coefficients & Structure coefficient $(R s)$ & Canonical cross-loadings $(R c)$ & Squared canonical loadings $\left(R c^{2}\right)$ \\
\hline \multicolumn{5}{|c|}{ Job embeddedness canonical variate/variables } \\
\hline Organisational fit & 0.57 & 0.85 & 0.57 & 0.32 \\
\hline Organisational links & 0.60 & 0.86 & 0.58 & 0.33 \\
\hline Organisational sacrifice & 0.00 & 0.83 & 0.55 & 0.30 \\
\hline \multicolumn{5}{|c|}{ Organisational commitment foci canonical variate/variables } \\
\hline Work foci & 0.10 & 0.43 & 0.29 & 0.08 \\
\hline Job foci & -0.18 & 0.46 & 0.30 & 0.09 \\
\hline Occupational foci & 0.53 & 0.68 & 0.45 & 0.20 \\
\hline Career foci & -0.35 & 0.22 & 0.15 & 0.02 \\
\hline Organisational foci & 0.84 & 0.91 & 0.61 & 0.37 \\
\hline
\end{tabular}

Notes: Sample size, $N=196$.

Overall model fit measures (function 1):

Overall $R c^{2}=0.44$

$\mathrm{F}(p)=7.25(p<0.0001) ; d f=15 ; 417.25$

Overall proportion: 0.93

Wilks's lambda $(\lambda)=0.528^{* * *}$

$r^{2}$-type effect size: $1-. \lambda=0.472$ (large practical effect)

Redundancy index (standardised variance of commitment foci explained by job embeddedness): Proportion $=0.15$

canonical correlation results. No significant associations were observed between the career foci variables and the overall JE fit and sacrifice variables. The associations between age, gender and race and the JES and OCS variables were mostly non-significant and small in practical effect and therefore regarded as negligible.

\section{Canonical correlations}

Canonical correlation analysis was used to study the multivariate relationships between the three JES variables (fit, sacrifice and links) and the five OCS scores (work foci, job foci, occupational foci, career foci and organisational foci).

Table 2 shows that the full model was significant, using Wilks's multivariate test criterion. Wilks's lambda $(\lambda)=0.528$, function $1: \mathrm{F} p=7.25$ ( $p=0.0001)$. Only the first function of the model was significant and contributed to $44 \%$ of the overall explained variation relative to the function. The full model $r^{2}$-type effect size (yielded by $1-. \lambda$ ) was 0.47 (large practical effect), indicating that the full model explains an adequate proportion, about $47 \%$ of the variance shared between the two variable sets. The redundancy index results summarised in Table 2 show that the job embeddedness capacities explained 15\% $\left(R c^{2}=29\right.$; moderate practical effect $)$ of the variance in organisational commitment foci and were able to predict $93 \%$ (large practical effect) of the proportion of variance in the individual original organisational commitment foci variables.

Table 2 provides the canonical coefficients (weights), canonical structure coefficients $(R s)$, canonical crossloadings $(R c)$ and squared canonical loadings $\left(R c^{2}\right)$. The five OCS variables all loaded positively with the organisational commitment canonical construct and were assumed to represent strong organisational commitment foci. Career foci $(R c=0.22)$ showed the lowest loading in comparison with organisational foci $(R c=0.91)$ and occupational foci $(R c=0.68)$.

Organisational links $(R c=0.86)$ and organisational fit $(R c=0.85)$ showed the highest loading with the job 
embeddedness canonical construct as measured by the JES, followed by organisational sacrifice $(R c=0.83)$.

Using $R c \geq 0.40$ as the cut-off value for interpreting the results, Table 2 further shows that the job embeddedness capacities contributed positively to explaining the variance in two of the original organisational commitment foci variables: organisational foci $(R c=0.61 ; 37 \%)$ and occupational foci $(R c=0.45 ; 20 \%)$. The organisational commitment foci variables contributed positively to explaining the variance in organisational links $(R c=0.58$; $33 \%)$, organisational fit $(R c=0.57 ; 32 \%)$ and organisational sacrifice $(R c=0.55 ; 30 \%)$.

\section{Discussions}

In this study, we sought (1) to ascertain whether a noteworthy relationship exists between a set of job embeddedness capacities and a set of organisational commitment foci and (2) to identify the variables that contributed the most to this relationship. Overall, the results showed positive associations between the job embeddedness capacities and organisational commitment foci constructs, especially pertaining to organisational foci and occupational foci.

The findings showed that organisational links and organisational fit contributed the most to strengthening the participants' organisational foci, as well as their occupational foci. These two organisational commitment foci represent a sense of commitment to an identifiable and specific line of work in which an individual engages in order to earn a living at a given point in time (Lee et al. 2000), as well as an individual's willingness to stay with the organisation by being more determined to fulfil the organisational values and goals. This finding corroborates research indicating that individual's loyalty will be determined by the extent to which the individual accepts the values and goals of the organisation as their own (Roodt 1997:8). The association between job embeddedness variables (fit, links and sacrifice) and organisational and occupational foci of commitment could be attributed to the fact that fit is associated with a sense of alignment with the organisational values and goals, links are associated with the relations between co-workers and the organisation, and sacrifice is associated with what an individual will lose when leaving an organisation.

The findings corroborate previous research by Williamson and Holmes (2015:225) that showed job embeddedness is relevant in a South African context and that there seems to be a positive relationship between job embeddedness and organisational commitment among individuals with low collectivism (such as black females). The findings further contributed empirical evidence in support of the view that organisational commitment foci seem to have a positive influence on the retention of valuable staff within an organisation (Rumvimbo \& Hlanganipai 2016:75).

\section{Practical implications}

The study suggests that developing employees' job embeddedness may strengthen their organisational commitment, specifically their organisational and occupational commitment foci. This research showed that organisational links and fit were positively associated with higher levels of occupational and organisational commitment foci within employees. Evidently, organisations should strive to strengthen both the psychological and financial association between the organisation and the individual. By building strong links, employees may feel bound psychologically to the organisation. This may increase an individual's sense of moral obligation of not leaving the organisation owing to the perceived sacrifices and risks they would have to take if they decided to resign from the organisation. According to Holtom and Inderrieden (2006:435), by using flexible work policies, teams and long-term projects, links can be increased. By connecting job and organisational rewards to tenure, sacrifice can be increased. Lastly, by matching an employee's personal attributes (e.g. career needs, values, desires, knowledge, skills and abilities) with a job's requirements, fit can be increased. Retention and talent management interventions should thus focus on strengthening fit with organisational values and goals, including meaningfulness of occupation within the organisation, which could relate to aspects of job embeddedness links and sense of what will be sacrificed if an individual decides to leave the job or occupation. By enhancing individuals' occupational and organisational commitment foci, organisations will be able to retain valuable staff (Ruvombo \& Hlanganipai 2016:75; Williamson \& Holmes 2015:225). Given the post-apartheid concerns of fair employment and leadership opportunities for black South Africans, organisations should focus on enhancing the job embeddedness and organisational commitment of previously disadvantaged groups.

\section{Limitations of the study}

Several limitations need to be considered in understanding these results. Firstly, canonical correlation analysis is a maximisation method, and in interpreting the results, researchers and practitioners should be aware of the risk of overestimation because of the amplification of linear composites (Hair et al. 2010). Secondly, the sample consisted of a relatively small group of participants within the HRM field. Thus, the results cannot be generalised to individuals in different occupations. Duplicating this study by using several multicultural populations within different occupational groups may add to the body of knowledge with regard to variables influencing retention for diverse groups of employees. Thirdly, the data were collected by means of self-report questionnaires. As a result of method variance limitation, spuriously strong relationships could have been found. Lastly, the cross-sectional nature of this study limits the nature of data obtained to a specific moment in time. 


\section{Recommendations}

Much would be gained by future longitudinal research analysing the shift in levels of job embeddedness and organisational commitment foci in terms of the retention of talented staff.

\section{Conclusions}

The findings of the study added new understandings to current retention theory, especially in a multicultural South African organisational context. This study provided empirical evidence in support of theoretical views on the psychological attributes underpinning individuals' job embeddedness and organisational commitment foci in the South African workplace. The multivariate approach in ascertaining the relationship between the two sets of variables helped to identify key job embeddedness capacities that influence individuals' foci of organisational commitment. It is hoped that the research will stimulate further research on factors influencing retention within the multicultural working environment (for both the individual and the organisation).

\section{Acknowledgements}

The authors acknowledge Prof. Melinde Coetzee for her valuable input and mentoring to make this article a reality.

\section{Competing interests}

The authors declare that they have no financial or personal relationships that may have inappropriately influenced them in writing this article.

\section{Authors' contributions}

I.L.P. was the project leader, who was responsible for experimental and project design. N.F. performed most of the experiments. I.L.P and N.F. made conceptual contributions. Calculations were performed by N.F. and interpretations were done by I.L.P.

\section{References}

Aryee, S., Chay, Y. \& Chew, J., 1994, 'An investigation of the predictors and outcomes of career commitment in the three career stages', Journal of Vocational Behaviour 44, 1-16. https://doi.org/10.1006/jvbe.1994.1001

Booysen, L., 2007, 'Barriers to employment equity implementation and retention of blacks in management in South Africa', South African Journal of Labour Relation 31(1), 47-71.

Bothma, F.C. \& Roodt, G., 2012, 'Work-based identity and work engagement as potential antecedents of task performance and turnover intention: Unravelling a complex relationship', South African Journal of Industrial Psychology 38(1), Art, \#893. https://doi,org/10.4102/sajip.v38i1.893

Brundage, H. \& Koziel, M., 2010, 'Retaining top talent: Still a requirement for firms', Journal of Accountancy, May, 38-44.

Burke, R.J. \& Ng, E., 2006, 'The changing nature of work and organisations: Implications for human resource management', Human Resource Management Review 16, 86-94. https://doi.org/10.1016/j.hrmr.2006.03.006

Chabault, D., Hulin, A. \& Soparnot, R., 2012, 'Talent management in clusters', Organisational Dynamics 41, 327-335. https://doi.org/10.1016/j.orgdyn.2012.08.008

Charlier, S.D., Guay, R.P. \& Zimmerman, R.D., 2016, 'Plugged in or disconnected? A model of the effects of technological factors on employee job embeddedness', Human Resource Management 55(1), 109-126. https://doi.org/10.1002/hrm.21716

Chetty, P., Coetzee, M. \& Ferreira, N., 2015, 'Sources of job stress and cognitive receptivity to change: The moderating role of job embeddedness', South African Journal of Psychology 46, 11-13. https://doi.org/10.1177/0081246315591308
Coetzee, M., 2015, 'Employees' psychosocial career preoccupations in relation to their work-related commitment', Southern African Business Review 19(3), 30-47.

Coetzee, M. \& De Villiers, M.A., 2010, 'Sources of job stress, work engagement and career orientations of employees in a South African financial institution', South African Business Review 14(1), 27-57.

Coetzee, M., Schreuder, A.M.G. \& Tladinyane, R.T., 2014, 'Employees' work engagement and job commitment: The moderating role of career anchors', South African Journal of Human Resource Management 12(1), Art. \#572. https://doi. org/10.4102/sajhrm.v12i1.572

Cohen, A., 2003, Multiple commitments in the workplace: An integrative approach, Lawrence, New York.

Cohen, J., 1992, 'Quantitative methods in psychology: A power primer', Psychological Bulletin 112(1), 153-159. https://doi.org/10.1037/0033-2909.112.1.155

Colarelli, S.M. \& Bishop, R.C., 1990, 'Career commitment functions, correlates and management', Group and Organisation Studies 15(2), 158-176. https://doi. org/10.1177/105960119001500203

Cramer, D. \& Howitt, D., 2011, The SAGE dictionary of statistics, Pearson Education Ltd, Essex.

Döckel, D., 2013, 'The effects of retention factors on organizational commitment: An investigation of high technology employees', Unpublished doctoral thesis, University of Pretoria, Pretoria.

Dyk, J.V. \& Coetzee, M., 2013, 'Organisational commitment and job embeddedness of service staff with critical and scare skills', South African Journal of Labour Relations 37(1), 61-78.

Feldman, D. \& Ng, T., 2007, 'Mobility, embeddedness, and success', Journal of Management 33(3), 350-377. https://doi.org/10.1177/0149206307300815

Felps, W., Hekman, D.R., Mitchell, T.R., Lee, T.W., Harman, W.S. \& Holtom, B.C., 2009 , 'Turnover contagion: How co-workers' job embeddedness and co-workers' job
search behaviours influence quitting', Academy of Management Journal 52(3), search behaviours influence quitting', Academy of Manag
545-561. https://doi.org/10.5465/AMJ.2009.41331075

Ferreira, N., 2010, 'The relationship between psychological career resources and organisational commitment', Unpublished master's dissertation, University of Pretoria, Pretoria.

Ferreira, N., 2012, 'Constructing a psychological profile for staff retention', Unpublished doctoral thesis, University of South Africa, Pretoria.

Ferreira, N. \& Coetzee, M., 2010, 'Psychological career resources and organisational commitment: Exploring socio-demographic differences', South African Journal of Labour Relations 34(2), 25-41.

Ferreira, N. \& Coetzee, M., 2014, 'Psychological career resources as predictors of employees' job embeddedness: An exploratory study', South African Journal of Labour Relations 38(2), 9-26.

Ferreira, N., Coetzee, M. \& Masenge, A., 2013, ‘Psychological career resources, career adaptability and hardiness in relation to job embeddedness and organisational commitment', Journal of Psychology in Africa 23(1), 31-40.

Ghosh, D. \& Gurunathan, L., 2015, 'Do commitment based human resource practices influence job embeddedness and intention to quit?', IIMB Management Review 27, 240-251. https://doi.org/10.1016/j.iimb.2015.09.003

Hair, J., Black, W., Babin, B. \& Anderson, R., 2010, Multivariate data analysis, Pearson Education, Pearson, NJ.

Halvorsen, B., Treuren, G.J.M. \& Kulik, C.T., 2015, 'Job embeddedness among migrants: Fit and links without sacrifice', The International Journal of Human Resource Management 26(10), 1298-1317. https://doi.org/10.1080/09585192.2 014.990399

Hebenstreit, R.K., 2008, A call to apply the principles of the enneagram in organisations to attract, retain and motivate employees, viewed 16 April 2016, from http:// researchpro.seals.ac.za

Hirschi, A., 2012, 'Callings and work engagement: Moderated mediation model of work meaningfulness, occupational identity, and occupational self-efficacy', Journal of Counseling Psychology 59(3), 479-485. https://doi.org/10.1037/ a0028949

Holtom, B.C., \& Inderrieden, E.J., 2006, 'Integrating the unfolding model and job embeddedness model to better understand voluntary turnover', Journal of Managerial Issues 4(XV111), 435-452.

Hom. P.W., Tsui, A.S., Wu, J.B., Lee, T.W., Zhang, A.Y. \& Li, L., 2009, 'Explaining employment relationships with social exchange and job embeddedness', Journa of Applied Psychology 94(2), 277-297. https://doi.org/10.1037/a0013453.

Kock, R., \& Burke, M., 2008, 'Managing talent in the South African public service', Public Personnel Management 37(4), 457-470. https://doi.org/10.1177/009102 Public Personnel

Lee, K., Carswell, J.J. \& Allen, N.J., 2000, 'A meta-analytic review of occupational commitment: Relations with person- and work-related variables', Journal of Applied Psychology 85, 799-811. https://doi.org/10.1037/0021-9010.85.5.799

Lee, T.W., Mitchell, T.R., Salblynski, J.C., Burton, P.J. \& Holtom, C.B., 2004, 'The effects of job embeddedness on organisational citizenship, job performance volitional absences and voluntary turnover', Academy of Management Journal 47(1), 711-722. https://doi.org/10.2307/20159613

Lumley, E., 2009, 'Exploring the relationship between career anchors, job satisfaction and organisational commitment', Unpublished master's dissertation, University of South Africa, Pretoria.

Marisi, S., Cox, S.S. \& Bennett, R.J., 2016, 'Job embeddedness: Is it always a good thing?' Journal of Managerial Psychology 31(1), 141-153. https://doi.org/ 10.1108/JMP-05-2013-0150 
Martin, A. \& Roodt, G., 2016, 'Perceptions of organisational commitment, job satisfaction and turnover intentions in a post-merger South African tertiary institution', South African Journal of Industrial Psychology 34(1), 23-31.

Meyer, J.P. \& Allen, N.J., 1997, Commitment in the workplace: Theory, research and application, Sage, Thousand Oaks, CA.

Meyer, J.P., Stanley, L.J., Herscovitch, L. \& Topolnytsky, L., 2002, 'Affective, continuance and normative commitment to the organization: A meta-analysis of antecedents, correlated and consequences', Journal of Vocational Behaviour 61, 20-52. https:// doi.org/10.1006/jvbe.2001.1842

Meyer, J.P., Stanley, L.J. \& Parfyonova, N.M., 2012, 'Employee commitment in context: The nature and implication of commitment profiles', Journal of Vocational Behaviour 80(1), 1-16. https://doi.org/10.1016/j.jvb.2011.07.002

Mitchell, T.R., Holtom, B.C. \& Lee, T.W., 2001, 'How to keep your best employees: Developing an effective retention policy', The Academy of Management Executive 15(4), 96-109. https://doi.org/10.5465/AME.2001.5897929

Meuller, C.W., Wallace, J.E. \& Prince, J.L., 1992, 'Employee commitment', Work and Occupations 19(3), 211-236. https://doi.org/10.1177/0730888492019003001

Mouton, J. \& Marais, H., 1996, Basic concepts in the methodology of the social sciences, 5th edn., HSRC, Pretoria.

Mowday, R.T., Porter, L.W. \& Steers, R.M., 1982, Employee-organisation linkages: The psychology of commitment, absenteeism and turnover, Academic Press, New York.

Oyewobi, L.O., Suleiman, B. \& Jamil, A.M., 2012, 'Job satisfaction and job commitment: A study of quantity surveyors in Nigerian Public Service', International Journal of Business and Management 7(5), 179-192. https://doi.org/10.5539/ijbm. v7n5p179

Podnar, K. \& Golob, U., 2015, 'The twin foci of organisational identification and their relevance for commitment: A study of marketing communication industry', Journal of Business Economic and Management 16(1), 214-227. https://doi.org/ 10.3846/16111699.2013.791636

Puah, P. \& Ananthram, S., 2006, 'Exploring the antecedents and outcomes of caree development initiatives: Empirical evidence from Singaporean employees', Research and Practice in Human Resource Management 14(1), 112-142.

Redelinghuys, K. \& Botha, E., 2016, 'Person-environment fit, job satisfaction and intentions to leave: The moderating effect of leader empowering behaviour', Journal of Psychology in Africa 26(1), 11-21.

Reiche, S., 2007, 'The effect of international staffing practices on subsidiary staff retention in multinational corporations', International Journal of Human Resource Management 18(4), 523-536. https://doi.org/10.1080/09585190601178711

Roodt, G., 1997, 'Theoretical and empirical linkages between work-related commitment foci', Journal of Industrial Psychology 23(2), 6-13. https://doi.org/ 10.4102/sajip.v23i2.624

Rubel, M.R.B. \& Kee, D.M.H., 2015, 'Perceived fairness of performance appraisal, promotion opportunity and nurses' turnover intention: The role of organisational commitment', Asian Social Science 11(9), 183.

Ruvimbo, T.S. \& Hlanganipai, N., 2016, 'Organisational commitment and job retention among nurses in a South African setting: An exploratory study', Journal of Psychology in Africa 26(1), 74-77.
Shaw, J.D., Delery, J.E., Jenkins, G.D. \& Gupta, N., 1998, 'An organization-level analysis of voluntary and involuntary turnover', Academy of Management Journal 41, 511-525. https://doi.org/10.2307/256939

Tabak, F. \& Hendy, N.T., 2016, 'Work engagement: Trust as a mediator of the impact of organizational job embeddedness and perceived organizational support', Organisation Management Journal 13(1) 21-31. https://doi.org/10.1080/15416 518.2015.1116968

Tabane, T., Bosch, A. \& Roodt, G., 2013, ‘Organisation value - Person value congruence and the relation to organisational commitment', South African Journal of Labour Relations 37(1), 39-60.

Tanova, C. \& Holtom, B.C., 2008, 'Using job embeddedness factors to explain voluntary turnover in four European countries', The International Journal of Human Resources Management 19(9), 1553-1568. https://doi.org/10.1080/0958519 0802294820

Tladinyane, R.T., Coetzee, M. \& Masenge, A., 2013, 'Psychological career metacapacities in relations to employees' retention-related dispositions', Southern African Business Review 17(2), 140-163.

Vandenberghe, C. \& Bentein, K., 2009, 'A closer look at the relationship between affective commitment to supervisors and organisations and turnover', Journal of Occupational and Organisational Psychology 82, 331-348. https://doi org/10.1348/096317908X312641

Van Dyk, J. \& Coetzee, M., 2012, 'Retention factors in relation to organisational commitment in a South African medical and information technology services
company', South African Journal of Human Resource Management 10(2), 1-11. company', South African Journal of Human
https://doi.org/10.4102/sajhrm.v10i2.433

Van Dyk, J., Coetzee, M. \& Takawira, N., 2013, 'Satisfaction with retention factors as predictors of the job embeddedness of medical and information technology staff', Southern African Business Review 17(1), 57-75.

Veurink, S.A. \& Fischer, R., 2011, 'A refocus of foci: A multidimensional and multi-foci examination of commitment in work context', New Zealand Journal of Psychology 40(3), 160-167.

Wasti, S.A. \& Onder, C., 2009, 'Commitment across cultures: Progress, pitfalls and propositions', In H.J. Klein, T.E. Becker \& J.P. Meyer (eds.), Commitment in organisations: Accumulated wisdom and new directions, pp. 309-343, Routledge Taylor and Francis Group, New York.

Williamson, I.O. \& Holmes, O., 2015, 'What's culture got to do with it? Examining job embeddedness and organizational commitment and turnover intentions in South Africa', African Journal of Management 1(3), 225-243. https://doi.org/10.1080/ 23322373.2015.1056649

Yousaf, A., Yang, H. \& Sanders, K., 2015, 'Effects of intrinsic and extrinsic motivation on task and contextual performance of Pakistani professionals', Journal of Manageria Psychology 30(2), 133-150. https://doi.org/10.1108/JMP-09-2012-0277

Yuan, B.J.C., Lin, M.B.H., Shieh, J. \& Li, K., 2012, 'Transforming employee engagement into long-term customer relationships: Evidence from information technology sales people in Taiwan', Social Behaviour and Personality 40(9), 1549-1554. https://doi.org/10.2224/sbp.2012.40.9.1549

Zhang, M., Fried, D.D. \& Griffeth, R.W., 2012, 'A review of job embeddedness: Conceptual measurement issues, and directions for future research', Human Resource Management Review 22(3), 220-231. https://doi.org/10.1016/j.hrmr 2012.02.004 